Features

\title{
Creating Living Landscapes: Why We Need to Increase Plant/Insect Linkages in Designed Landscapes
}

\author{
Douglas W. Tallamy ${ }^{1}$
}

ADDITIONAL INDEX WORDs. host plant specialization, ecosystem services, biodiversity, landscape design, environmental landscape

SumMARY. Specialized relationships between animals and plants are the norm in nature rather than the exception and landscape designs that destroy them also degrade local ecosystem function. Plants that evolved in concert with local animals provide for their needs better than plants that evolved elsewhere. The most common and arguably most important specialized relationships are those that have developed between insect herbivores and their host plants. Here, I explain why this is so, why specialized food relationships determine the stability and complexity of the local food webs that support animal diversity, and why our yards and gardens are essential parts of the ecosystems that sustain us. I also discuss how we can use our residential and corporate landscapes to connect the isolated habitat fragments around us and produce valuable ecosystem services, and what we can do to make our landscapes living ecosystems once again.

A $s$ the human footprint continues to expand at the expense of the natural capital that sustains us, there is a growing need and increasing demand for residential, corporate, urban, and suburban landscapes that generate natural resources rather than destroy them. At our current population levels, a culture that segregates humans from nature is not a sustainable option and by whittling away at functional ecosystems, such a culture has led to a reduction in the earth's ability to produce essential renewable resources (also known as ecosystem services) by more than $60 \%$ (Millennium Ecosystem Assessment, 2005).

Department of Entomology and Wildlife Ecology, University of Delaware, Newark, DE 19716.

${ }^{1}$ Corresponding author. E-mail: dtallamy@udel.edu. doi: 10.21273/HORTTECH03699-17
To believe there will always be sufficient oxygen, clean air and water, carbon sequestration, pollinators, and the biodiversity that produces these resources, regardless of how we treat local landscapes, or to suggest that technology can effectively replace them is folly in its most misguided form.

Fortunately, we already have the knowledge required to integrate human habitats with the natural world. Indeed, the concept itself is ironic because humans are products of the natural world-one of millions of life forms that natural systems sustain every day-and we have never been even partially independent of earth's bounty. What types of landscapes are capable of sustaining humans and nature simultaneously? Ones that feature plants that interact with the species around them. Such plants are the key; every ecosystem service required by humans (and most other animals as well) is created either directly or indirectly by plants. We have degraded ecosystem function by removing plants from local ecosystems, or by assuming that all plants function equally well in every environment. It follows that we can repair the damage we have inflicted on the typically built landscape simply by putting the right plants back. And who better to lead the way in this most noble endeavor than landscape architects and designers.

Unfortunately, most professionals in these two careers have not been trained in the fundamentals of "ecological landscaping." Instead, programs in landscape architecture and design have followed a centuries-old tradition of treating plants as tools of creativity: decorations that can be combined with artistic hardscape to create beauty in our surrounds. Plants are indeed inherently beautiful but they are far more than that; plants are essential to sustaining life, both on earth and in our gardens. We need to expand our expectations of what plants must do in designed landscapes to include their critical ecological roles and encourage new cross-discipline collaborations among entomologists, restoration ecologists, and the horticultural community to accomplish this. This article will discuss features common to all living landscapes and suggests simple strategies for incorporating them into our designed spaces.

\section{Nature equals specialized relationships}

A pattern is emerging from conservation efforts around the world; if you want to save a particular species, you have to save the specialized relationships that support that species. If, for example, you want to save the resplendent quetzal (Table 1 ), a gorgeous but endangered bird in Central America, you have to restore populations of wild avocado trees because the fruits of that species are an essential component of the resplendent quetzal diet. If you want to save jaguars, you need to protect large populations of palm species that make small palm nuts (as opposed to coconuts). Why these palms? Because palm nuts are a critical and 
Table 1. Taxonomic identification of organisms discussed in this article.

\begin{tabular}{|c|c|}
\hline Common name & Taxonomic nomenclature \\
\hline \multicolumn{2}{|l|}{ Birds } \\
\hline Bluebirds & Sialia species \\
\hline Buntings & Passerina species \\
\hline Carolina chickadee & Poecile carolinensis \\
\hline Crossbills & Loxia species \\
\hline Doves & Zenaida species \\
\hline Finches & Fringillidae \\
\hline Flyctachers & Tyranni \\
\hline Great green macaw & Ara ambiguus \\
\hline Gray catbird & Dumetella carolinensis \\
\hline Hummingbirds & Trochilidae \\
\hline Northern cardinal & Cardinalis cardinalis \\
\hline Orioles & Icterus species \\
\hline Red bellied woodpecker & Melanerpes carolinus \\
\hline Resplendent quetzal & Pharomachrus mocinno \\
\hline Tufted titmouse & Baeolophus bicolor \\
\hline Tree swallow & Tachycineta bicolor \\
\hline Wood thrush & Hylocichla mustelina \\
\hline \multicolumn{2}{|l|}{ Mammals } \\
\hline Black bear & Ursus americanus \\
\hline Foxes & Vulpes species \\
\hline Jaguar & Panthera onca \\
\hline Peccaries & Pecari species \\
\hline Raccoon & Procyon lotor \\
\hline \multicolumn{2}{|l|}{ Reptiles } \\
\hline Eastern box turtle & Terrapene carolina \\
\hline \multicolumn{2}{|l|}{ Amphibians } \\
\hline Frogs & Anura species \\
\hline Toads & Anura species \\
\hline \multicolumn{2}{|l|}{ Arthropods } \\
\hline Spiders & Araneae \\
\hline \multicolumn{2}{|l|}{ Insects } \\
\hline \multicolumn{2}{|l|}{ Lepidoptera } \\
\hline Hummingbird sphinx & Hemaris thysbe \\
\hline Nessus sphinx & Amphion floridensis \\
\hline Snowberry clearwing & Hemaris diffinis \\
\hline \multicolumn{2}{|l|}{ Coleoptera } \\
\hline Ladybird beetles hymenoptera & Coccinellidae \\
\hline Ants & Formicidae \\
\hline Bees & Apoidea \\
\hline Digger wasps & Crabronidae \\
\hline \multicolumn{2}{|l|}{ Hemiptera } \\
\hline Assassin bugs & Reduviidae \\
\hline Damsel bugs & Nabidae \\
\hline Stinkbugs & Pentatomidae \\
\hline \multicolumn{2}{|l|}{ Neuroptera } \\
\hline Lacewings & Chrysopidae \\
\hline \multicolumn{2}{|l|}{ Plants } \\
\hline Black-eyed susan & Rudbeckia birta \\
\hline Mayapple & Podophyllum peltatum \\
\hline Palms & Arecaceae \\
\hline Virginia creeper & Parthenocissus quinquefolia \\
\hline Wild almond & Dipteryx panamensis \\
\hline Wild avacado & Persea americana \\
\hline
\end{tabular}

substantial part of the diet of peccaries, the wild pigs that are jaguar prey. If you want great green macaws in the future, you need to restore populations of wild almond trees because they are the only trees those birds will nest in. Such specialized relationships are so common in the tropics that they are the rule rather than the exception.

What surprises many, however, is that specialized relationships, particularly involving food webs, are also the rule in the temperate zone, and we cannot create living landscapes if we exclude them. If you want may apples to spread by seed, you need a population of box turtles. May apple seeds germinate best after passing through the gut of a box turtle that has eaten the may apple fruit. If you want pileated woodpeckers in your neighborhood you need trees that harbor large colonies of carpenter ants because carpenter ants are what these birds feed their young. If you want your wild blue phlox to produce viable seed, you need the plants that support the larval development of day-flying sphinx moths (native viburnums for the hummingbird moth or native coral honeysuckle for the snowberry clearwing or virginia creeper for the nessus sphinx), for these moths are the primary pollinators of phlox.

Even species that do not seem to depend on any specialized relationships often do, especially during reproduction. Chickadees provide an excellent example. As anyone with a bird feeder knows, chickadees are seed-eaters during the fall, winter, and early spring. When the time comes to feed the young, however, chickadees join $96 \%$ of the terrestrial birds in North America and rear their young on insects (data from Dickinson, 1999) and not just any insect; they feed nestling caterpillars, the larvae of moths, butterflies, and sawflies. Chickadee parents could feed their young other abundant insects, but the overwhelming majority of their prey during reproduction is caterpillars. Those are not just any caterpillar, but those that are not covered in hairs or spines. Because chickadees rear their young on caterpillars, there will be no chickadees where there are not enough caterpillars to bring a clutch of eggs to independence from parental care.

How many caterpillars are required to produce a clutch of chickadees? Carolina chickadees bring somewhere between 390 and 570 caterpillars to their nest each day, depending on the number of chicks 
in the nest (Brewer, 1961). Parents feed nestlings in the nest for 16$18 \mathrm{~d}$ before the young fledge and then for $30 \mathrm{~d}$ or more after fledging. If we focus only on the caterpillars required to reach fledging, it takes 6240-10,260 caterpillars to fledge a single clutch of chickadees, an astounding number, even to those who study bird behavior. No one knows how many more caterpillars are required during the $30 \mathrm{~d}$ after fledging. What's more, chickadees are tiny birds; a carolina chickadee weighs a third of an ounce, the equivalent of four pennies. In comparison, a red-bellied woodpecker, which also rears its young on insect larvae, weighs eight times more than a chickadee. How much insect biomass is required to create a redbellied woodpecker? How many insects are required to sustain an entire population of chickadees and woodpeckers . . . and titmice, and orioles, bluebirds, wood thrushes, catbirds, cardinals, buntings, flycatchers, and all of the other birds that signal healthy temperate zone ecosystems? The numbers are mindboggling.

\section{Consequences of specialization}

Suggesting that designed landscapes should produce rather than destroy insects would have been ludicrous if not heretical in the past. After all, if plants are simply decorations, we would want them to be forever flawless and untouched by natural processes. In fact, if flawless plantings are really the goal, using silk or plastic plants seems like the more logical option. If our goal, however, is to create landscapes that contribute to rather than detract from local ecosystem function, then we must include "the little things that run the world" (Wilson, 1987). Decades of research have shown that insects are essential for pollination, nutrient recycling, pest control, and for feeding many other animals. A world without insects is a world without biological diversity; and a world without biological diversity is a world without humans. If insects were to disappear, humans would not last more than a few months (Wilson, 1987). In this light, waging war insects where we live, work, farm, and play seems counter-productive at best.

How, then, can we design landscapes that support a diversity of insect species that stay in a balanced equilibrium with the natural enemies that control them? Before we answer this question, we have to consider the most important and abundant specialized relationship on the planet: the relationship between the insects that eat plants and the plants they eat. Most insect herbivores, some $90 \%$, in fact, are diet specialists (Bernays and Graham, 1988; Forister et al., 2015). Just like breeding chickadees, they are restricted to eating just a few lineages of plants. Plants, of course, do not want to be eaten. They want to capture the energy from the sun and use it for their own growth and reproduction, so they manufacture nasty tasting chemicals specifically to deter plant eaters. These chemicals are secondary metabolic compounds that do not contribute to the primary metabolism of the plant. Their job is to make various plant parts distasteful or downright toxic to insect herbivores. Some well-known plant defenses include toxic compounds like cyanide, nicotine, cucurbitacins, and pyrethrins; heart-stoppers like cardiac glycosides; and digestibility inhibitors like tannins.

If plants are so well defended, how can insects eat them without dying? This question dominated plant-insect interaction studies for three decades, but at this point, the answer has been thoroughly delineated. Caterpillars and other immature insects are eating machines; some species increase their mass 72,000 fold by the time they reach their full size (Imms et al., 1977). Because caterpillars necessarily ingest chemical deterrents with every bite, there is enormous selection pressure to restrict feeding to plant species they can eat without serious ill effects. Thus, a gravid female moth will lay eggs only on plants with chemical defenses their hatchling caterpillars are able to disarm.

There are many physiological mechanisms by which caterpillars can temper plant defenses, but they all involve some combination of sequestering, excreting, and detoxifying defensive phytochemicals contained before they interfere with the caterpillar's health. Caterpillars typically come by these adaptations through thousands of generations of exposure to the plant lineage in question, although occasionally they coincidentally possess enzymes that are able to disarm an evolutionarily novel plant (Rosenthal and Berenbaum, 2012). In short, by becoming host plant specialists, insect herbivores can circumvent plant defenses of a few plant species well enough to make a living, while ignoring the rest of the plants in their ecosystem.

Does this mean specialists have won the evolutionary arms race with plants? Somewhat, but only in relation to the plant lineage on which they have specialized. When viewed across all lineages, plant defenses are very effective at deterring most insects. The monarch butterfly provides an excellent example. This species is a specialist on milkweeds that use various forms of toxic cardiac glycosides to protect their tissues. They also defend their tissues with a milky latex sap that jells on exposure to air. Insects that eat the sap soon find their mouthparts glued permanently shut. Because of their specialized physiological adaptations to detoxify cardiac glycosides and behavioral adaptations to avoid the sticky latex sap, monarch caterpillars can eat milkweeds that are not viable host plants for most other insect herbivores (Dussourd and Eisner, 1987).

The advantage of this relationship is obvious for the monarch, but there are disadvantages to specializing, especially in today's world. Unfortunately for the monarch, the ability to detoxify cardiac glycosides in milkweeds does not confer the ability to disarm the chemical defenses found in other plant lineages. This means that of the 2137 native plant genera in the United States, the monarch can develop on only one, the milkweed genus. The evolutionary history of this butterfly has locked it into a dependent relationship with milkweeds and if milkweeds should disappear from a landscape, so would the monarch. And this is exactly what has happened across the United States in recent years. A growing culture that favors neat, manicured agricultural fields combined with an unwillingness to share designed landscapes with milkweeds has reduced monarch populations $96 \%$ from their numbers in the 1970s. Can monarchs 
adapt to other plant species? In theory yes, but in reality no. Monarchs have been genetically locked into a relationship with milkweeds for millions of years. Adaptation could conceivably modify this relationship very slowly over enormously long periods, but asking monarchs to suddenly (within 30 years!) switch their dependence to an entirely different plant lineage, say, for example crape myrtle, is like asking humans to develop wings. The number of genetic changes required to make such a switch reduces the probability of it happening before monarchs disappear to near zero.

Please note that monarchs are not exceptions, either in their specialized relationship with milkweeds or in their current plight. They are typical of $90 \%$ of the insects that eat plants; their evolutionary history has restricted their development and reproduction to only the plant lineage on which they have specialized, and as we have homogenized plant diversity around the world by replacing diverse native plant communities with a small palate of ornamental favorites from other lands, the insects that depend on native species have declined. Data from Europe paint an alarming picture; insects in Germany have declined in abundance and diversity 5.3 -fold since 1989. This includes the extinction of 46 species of butterflies and moths. Globally, invertebrate abundance has been reduced $45 \%$ since 1974 (Schwageral, 2016). We have caused these declines by the way we have designed landscapes in the past. But we can reverse them by the way we design landscapes in the future.

\section{Making insects}

What type of landscape is capable of producing insects in the numbers required to support viable food webs? A landscape created from the plants that have each developed specialized relationships with a diversity of insect species. A landscape occupied by organisms that have interacted with each other over evolutionary rather than ecological time spans. A landscape that showcases specialized relationships rather than ignores them. As we have seen, diet specialization is the rule among insect herbivores, not the exception. Without the plant lineages that support insect herbivores, there would be no insect herbivores (Narango et al., 2017). If there were no insect herbivores, all of the creatures that depend on insect herbivores for their nutrition, that is, the insectivores of the world, would also disappear. A world without insectivores would be a world without spiders; insect predators and parasitoids; frogs, toads, and other amphibians; lizards; bats, rodents, skunks, opossums, raccoons, as well as mammals we do not think of as insect-eaters, such as foxes and black bears, both of which get a quarter of their nutrition from insects (Wilson, 1987). Studies have shown that even some freshwater fish get more than $50 \%$ of their protein from terrestrial insects that fall into the water (Sullivan et al., 2012). And let us not forget that a world without insect herbivores would also be a world without most terrestrial bird species; with the exception of doves, finches, crossbills, and our largest birds of prey, terrestrial birds rear their young on insects and the spiders that ate insects to become spiders. To reiterate, a world without all of these creatures would not only be a world without biological diversity, it would be a world in ecological collapse that is incapable of supporting humans (Wilson, 1987).

\section{Biodiversity and ecosystem function}

Research over the decades has tied the number of interacting species in an ecosystem to both ecosystem function and ecosystem stability. Let us first consider ecosystem function. We can define ecosystem function in several ways: the ability to hold energy captured from the sun within biological systems before it escapes back into space; the ability to produce products or perform services useful to humans and other species; the ability to create living and dead biomass; and so on. In 1955, famed ecologist Robert MacArthur predicted that ecosystem function would increase linearly as the number of species within an ecosystem increased (MacArthur, 1955). Diverse ecosystems with many equally abundant species would be more productive than species-poor ecosystems dominated by one or a few species. Although no one had tested this prediction, it was logically appealing and soon came to be known as the Law of Nature.
It was not until 1981 that MacArthur's Law was challenged by an analogy between species populating an ecosystem and the rivets that once held airplanes together (Ehrlich and Ehrlich, 1981). In their rivet hypothesis, Paul and Anne Erhlich suggested that ecosystem productivity was indeed tied to the number of species in an ecosystem, but only to a point. Their hypothesis introduced the concept of species redundancy; the Erhlichs reasoned that there was redundancy in the species performing particular roles within ecosystems just as there was redundancy in aircraft rivets. An airplane could lose some rivets before a wing fell off the plane, and an ecosystem could lose some species before it suffered a measurable loss in productivity.

Generalist pollinators provide an example of species redundancy. A black-eyed susan needs to be pollinated before it can produce seeds, but many species of bees, moths, butterflies, beetles, and even ants are capable of doing the job (although not all do it equally well). The redundancy in black-eyed susan pollinators implies that one or even several of these pollinator species could disappear from the system without a reduction in seed set in black-eyed susan. Similarly, landscapes that produce dozens of species of caterpillars are far more stable in the eyes of reproducing birds than landscapes that produce just a few (Tallamy, 2004). In years with weather unfavorable to caterpillars, there would not be enough food to rear young in landscapes with only a few caterpillar species. In those with many species, however, several caterpillar species in combination would yield enough food so that birds could reproduce every year, regardless of the weather. Thus, caterpillar diversity in the landscape creates food web stability.

The rivet hypothesis was somewhat comforting to ecologists because it predicted that the local or global extinction of some species would not send ecosystems spiraling into collapse, at least not right away. Replicated studies of entire ecosystems in which distracting variables are controlled are extremely difficult to conduct, and so the compelling logic of both MacArthur's Law of Nature and the Ehrlich's rivet hypothesis remained untested for many years 
after it was proposed. In 2012, however, three studies were published that support MacArthur's predictions over those of the rivet hypothesis (Maestre et al., 2012; Naeem et al., 2012; Reich et al., 2012). As the number of species in an ecosystem goes up, so does ecosystem function and stability. Redundancy in the roles species play within ecosystems surely exists, yet studies now show that it does not buffer ecosystems from a loss of productivity every time a species disappears from the system. Not good news. If this relationship is borne out by additional research, we can no longer be complacent about the loss of species from local ecosystems.

New evidence suggests there is an important caveat to MacArthur's prediction. Lee Dyer and colleagues are showing that it is not actually the number of species in an ecosystem that controls ecosystem function, but rather, it is the number of interactions among species (Dyer et al., 2010; Scherrer et al., 2016). This explains why invasive plants are decreasing rather than increasing ecosystem function around the world. When a plant from outside of a local food web moves into a new ecosystem, it either displaces native plants species, reducing the total number of species in the area, or it joins them without significantly reducing species richness. In either case, the number of interactions among species declines. Non-native plants are just meeting the plants and animals in the "novel" ecosystem for the first time in evolutionary history (Hobbs et al., 2006), which means they have not had the time to develop the adaptations required to interact with many of the other species in that ecosystem. That is, species dependent on specialized relationships with particular plant lineages either become less abundant or disappear altogether if their native plant lineage is competitively excluded by the invasive plant. When bush honeysuckle from Asia, for example, displaces native spicebush in the understory of eastern forests or in our designed landscapes, the spicebush swallowtail loses some or all of its host plants and the number of interactions in that space decreases. Such losses are multiplied every time a native plant is pushed from a landscape (van Hengstum et al., 2013).

\section{Which plants should we use?}

If non-native ornamentals do not support the relationships required to restore ecosystem function to our landscapes, which plants do? Simple logic tells us that using a palette biased toward native species should be sufficient to support robust food webs in our landscapes. However, comparisons among plant genera of host records for moths and butterflies, the backbone of most terrestrial food webs, reveal two striking patterns that suggest this conclusion needs to be refined (Tallamy and Shropshire, 2009). First, there are huge differences among plant genera in their ability to make caterpillars and thus support creatures in higher trophic levels. Oaks in the mid-Atlantic states, for example, serve as host plants for 557 species of caterpillars, tulip poplars only feed 21 species, and yellowwoods are not used by any caterpillars. These are order of magnitude differences among plant genera that are all native to eastern North America. Second, a mere $5 \%$ of the native plant genera in any North American ecosystem support $73 \%$ to $75 \%$ of the caterpillar species. Stated in reverse, $95 \%$ of the native plant genera support only $25 \%$ to $27 \%$ of the caterpillars that drive local food webs (D.W. Tallamy, D.L. Narango, and K.J. Shropshire, unpublished). We cannot build ecologically rich landscapes if we do not include the core genera, those top 5\% that create most food driving local food webs.

We do not yet understand why some plant genera are responsible for so much of the life around us while most pass on minimal energy and some none at all to local wildlife, but we do not need to understand the basis of the relationship to use it effectively in landscape design. This pattern is consistent across all bioregions of North America and is not changed by latitude, longitude, or plant diversity levels. Wherever we are in the United States, we can create plantings that sustain birds, reptiles, amphibians, and mammals by generating tens of thousands of insects. Landscape designers and architects, land managers, restoration biologists, and homeowners can learn which native plant genera contain core species, as well as where to obtain these species, at the National Wildlife
Federation website under "Native Plant Finder" (National Wildlife Federation, 2017). Enter your zip code and a list of plant genera found in your county, ranked from most to least productive, will appear.

\section{Creating trophic balance}

Because our past goal in constructing built landscapes has been to create beauty using plants rather than to restore ecological integrity, a primary concern has been the aesthetic appeal of the plants themselves. A specimen unmarred by insect damage has been the ideal. As we have seen, though, an unmarred plant is one that has not interacted with other species in our landscapes, and a landscape full of unmarred plants is an ecologically depauperate space devoid of animal life. Is it possible to choose plants that are simultaneously beautiful and productive? Plants that can pass some of their energy on to the insect herbivores that can then support a vibrant community of other species? Indeed, it is but to do so we must attract even more species to our landscapes.

When species interact over long periods of time, a balance among plants, herbivores, and natural enemies (predators, parasites, parasitoids, and diseases) emerges that typically keeps any one species from eliminating the others. This is the ideal we should strive for in our built landscapes. If we use native plants that support dozens of species of insect herbivores, we will create a food resource for the natural enemies of those insects, so they too will become residents in the landscape and will keep insect populations below the aesthetic injury level. The spiders, assassin bugs, damsel bugs, ladybird beetles, lacewings, predatory stink bugs, digger wasps, parasitic Hymenoptera, bluebirds, tree swallows, cardinals, hummingbirds, catbirds, and many other insectivores all kill tens of thousands of insect herbivores before plants suffer noticeable damage. But natural enemies will not be in our landscapes if there is not enough food to support them. Fortunately, we have some wiggle room here, for studies have shown that people do not even notice insect damage until about $10 \%$ of the leaves have been eaten (Sadof and Raupp, 1996). Most plants are viewed at a distance; even 
the oak tree that supports hundreds of caterpillars looks untouched from 20 feet away.

\section{Using more plants}

Creating vibrant landscapes that become functional extensions of local ecosystems can only happen if we use the plants that drive those ecosystems. Choosing the right plants is a necessary first step, but we must also put enough of those plants into the landscape to achieve the ecosystem integrity we desire (Aronson et al., 2017). Today many of our built landscapes are dominated by turfgrass. For example, $92 \%$ of the area that could be landscaped in residential neighborhoods in northeast Maryland, southeast Pennsylvania, and Delaware is lawn. Moreover, $90 \%$ of the trees are gone from these landscapes and $79 \%$ of the plants that are there are from Asia (D.W. Tallamy, J. Bruck, S. Walker, K. Pippins, S. Shpak, and A. Lucey, unpublished). We have favored large lawns bearing few plants for two reasons: first, we prefer savanna-like landscapes, presumably because we feel safer in such environments (Falk and Balling, 2010). Large flawless lawns have also been a status symbol of the rich for centuries. Such landscapes may have met our physical and social needs when we were hunter-gathers, but they are an environmental disaster in today's world of 7.5 billion people. We are converting all built landscapes into lawn dominated spaces that do not support ecosystem function. To be sure, expanses of lawn are necessary for games and picnics, but there are few people who use all of their lawn for these activities. We now have over 40 million acres (16.2 million hectares) of lawn in the United States, an area roughly the size of New England, and we are adding $500 \mathrm{mile}^{2}\left(1295.0 \mathrm{~km}^{2}\right)$ more lawn each year (Kolbert, 2008; Milesi et al., 2005).

\section{Raising the bar}

To achieve a sustainable relationship with the earth we must raise the bar for what we ask of our built landscapes. In the past, we have asked that they be attractive and welltended spaces. We have achieved this in a grand style. But our need for ecosystem services is now so great that we can no longer rely on the remaining degraded and fragmented "natural" spaces to produce enough. We must now design beautiful landscapes that also support complex food webs that in turn support the biodiversity that runs our ecosystems. We need landscapes that sequester carbon; lawn sequesters 27 times less carbon than a meadow and 32 times less than a forest (Schwartz, 2014). We also need landscapes that clean and manage water. A lawn-dominated landscape impedes infiltration, creates disastrous storm water runoff, and adds nutrient and pesticides pollutants to aquatic ecosystems. Finally, we need to design landscapes that support diverse pollinator populations. Pollinators across the United States are in steep decline due to large part in the loss of nesting sites and seasonally abundant forage (Kremen et al., 2007). Manicured lawns provide neither resource. Pollinators, including the 4000 species of native bees that did all of the pollination in North America before the introduction of the honeybee, are not optional. They pollinate $80 \%$ of all plants and $90 \%$ of all flowering plants. If we were to lose pollinators, we would lose $80 \%$ to $90 \%$ of all plants including one-third of our crop species.

\section{Homegrown national park}

We have it in our power to create a new national park of sorts simply by redesigning the landscapes in which we live, work, and play. If we were to replace half of the area now in lawn with three-dimensional plantings of powerful native plant communities, we could create over 20 million acres of spaces that generate rather than destroy ecosystem services. Our "Homegrown National Park" will be enormous-bigger than all of the major national parks combined-and it will provide us with many of the benefits we derive from visiting our official national parks. Just $15 \mathrm{~min}$ in the solitude of a well-planted garden can lower blood pressure, reduce stress (cortisol), improve attention span, raise immune responses, and provide unlimited entertainment as we observe the life around us (Louv, 2005, 2012, 2016; Wolf, 2014). We will no longer lament over our disconnection with nature because we will live in its midst. Our new plantings will fill the gaps between fragmented natural areas, creating biological corridors that reconnect them. If habitat fragments are reconnected, they will support populations that are large enough to withstand normal stochastic fluctuations without disappearing. Our new park will not perfectly replicate the plant and animal communities that once existed on these sites, but it will reassemble the local relationships between plants and animals that coevolved over the eons and that are necessary for ecosystem function. Its design and maintenance will be so different from traditional practices that it could spawn a new ecological landscaping industry, one that can balance aesthetic and artful design with ecological function and reverse the declining interest in horticulture we have seen since 2008. To be sure this is an optimistic view of our future but it is entirely or largely obtainable and will have enormous ecological payoffs both for humans and our fellow earthlings.

\section{Literature cited}

Millennium Ecosystem Assessment. 2005. 2005 Millenium ecosystem assessment. 30 Apr. 2017. <http://www. millenniumassessment.org/en/index. html/>.

Aronson, M.F.J., C.A. Lepczyk, K.L. Evans, M.A. Goddard, S.B. Lerman, J.S. MacIvor, C.H. Nilon, and T. Vargo. 2017. Biodiversity in the city: Key challenges for urban green space management. Front. Ecol. Environ. 15:189-196.

Bernays, E.M. and M. Graham. 1988. On the evolution of host specificity in phytophagous arthropods. Ecology 69:886892.

Brewer, R. 1961. Comparative notes on the life history of the carolina chickadee. Wilson Bull. 73:348-373.

Dickinson, M.B. 1999. Field guild to the birds of North America. 3rd ed. Natl. Geographic Soc., Washington, DC.

Dussourd, D.E. and T. Eisner. 1987. Vein-cutting behavior: Insect counterploy to the latex defense of plants. Science 237:898-901.

Dyer, L.A., T.R. Walla, H.F. Greeney, J.O. Stireman, III, and R.F. Hazen. 2010. Diversity of interactions: A metric for studies of biodiversity. Biotropica 42:281289.

Falk, J.H. and J.D. Balling. 2010. Evolutionary influence on human landscape preference. Environ. Behav. 42:479-493. 
Forister, M.L., V. Novotny, A.K. Panorska, L. Baje, Y. Basset, P.T. Butterill, L. Cizek, P.D. Coley, F. Dem, I.R. Diniz, P. Drozd, M. Fox, A. Glassmire, R. Hazen, J. Hrcek, J.P. Jahner, O. Kama, T.J. Kozubowski, T.A. Kursar, O.T. Lewis, J. Lill, R.J. Marquis, S.E. Miller, H.C. Morais, M. Murakami, H. Nickel, N. Pardikes, R.E. Ricklefs, M.S. Singer, A.M. Smilanich, J.O. Stireman, S. Villamarín-Cortez, S. Vodka, M. Volf, D.L. Wagner, T. Walla, G.D. Weiblen, and L.A. Dyer. 2015. Global distribution of diet breadth in insect herbivores. Proc. Natl. Acad. Sci. USA 112:442-447.

Louv, R. 2005. Last child in the woods. Algonquin Books, Chapel Hill, NC.

Louv, R. 2016. Vitamin N: The essential guide to a nature-rich life. Algonquin Books, Chapel Hill, NC.

Louv, R. 2012. The nature principle: Reconnecting with life in a virtual world. Algonquin Books, Chapel Hill, NC.

Hobbs, R.J., S. Arico, J. Aronson, J.S. Baron, P. Bridgewater, V.A. Cramer, P.R. Epstein, J.J. Ewel, C.A. Clink, A.E. Lugo, D. Norton, D. Ojima, D.M. Richardson, E.W. Sanderson, F. Valladeres, M. Vila, R. Zamora, and M. Zobel. 2006. Novel ecosystems: Theoretical and management aspects of the new ecological world order. Glob. Ecol. Biogeogr. 15:1-7.

Imms, A.D., O.W. Richards, and R.G. Davies (eds.). 1977. Imms' general textbook of entomology. Vol. 1, 10th ed. Structure, physiology and development. Wiley, New York, NY.

Kolbert, E. 2008. Turf war. 15 Nov. 2016. <http://www.newyorker.com/magazine/ 2008/07/21/turf-war-elizabeth-kolbert>.

Kremen, C., N.M. Williams, M.A. Aizen, B. Gemmill-Herren, G. LeBuhn, R. Minckley, L. Packer, S.G. Potts, T.A. Roulston, I. Steffan-Dewenter, D.P. Vázquez, R. Winfree, L. Adams, E.E. Crone, S.S. Greenleaf, T.H. Keitt, A.M. Klein, J. Regetz, and T.H. Ricketts. 2007.
Pollination and other ecosystem services produced by mobile organisms: A conceptual framework for the effects of landuse change. Ecol. Lett. 10:299-314.

Maestre, F.T., J.L. Quero, N.J. Gotelli, A. Escudero, V. Ochoa, M. DelgadoBaquerizo, M. Garcia-Gomez, M.A. Bowker, S. Soliveres, C. Escolar, P. GarciaPalacios, M. Berdugo, E. Valencia, B. Gozalo, A. Gallardo, L. Aguilera, T. Arredondo, J. Blones, B. Boeken, D. Bran, A.A. Conceicao, O. Cabrera, M. Chaieb, M. Derak, D.J. Eldridge, C.I. Espinosa, A. Florentino, J. Gaitan, M.G. Gatica, W. Ghiloufi, S. Gomez-Gonzalez, J.R. Gutierrez, R.M. Hernandez, X.W. Huang, E. Huber-Sannwald, M. Jankju, M. Miriti, J. Monerris, R.L. Mau, E. Morici, K. Naseri, A. Ospina, V. Polo, A. Prina, E. Pucheta, D.A. Ramirez-Collantes, R. Romao, M. Tighe, C. Torres-Diaz, J. Val, J.P. Veiga, D.L. Wang, and E. Zaady. 2012. Plant species richness and ecosystem multifunctionality in global drylands. Science 335:214-218.

Milesi, C., S.W. Running, C.D. Elvidge, J.B. Dietz, B.T. Tuttle, and R.R. Nemani. 2005. Mapping and modeling the biogeochemical cycling of turf grasses in the United States. Environ. Manage. 36:426438 .

Naeem, S., J.E. Duffy, and E. Zavaleta. 2012. The functions of biological diversity in an age of extinction. Science 336:1401-1406.

Narango, D.L., D.W. Tallamy, and P.P. Marra. 2017. Native plants improve breeding and foraging habitat for an insectivorous bird. Biol. Conserv. 213:42-50.

National Wildlife Federation. 2017. Native plant finder. 13 June $2017 .<$ http:// www.nwf.org/NativePlantFinder/>.

Reich, P.B., D. Tilman, F. Isbell, K. Mueller, S.E. Hobbie, D.F.B. Flynn, and N. Eisenhauer. 2012. Impacts of biodiversity loss escalate through time as redundancy fades. Science 336:589-592.

Rosenthal, G. and M. Berenbaum (eds.). 2012. Herbivores: Their interactions with secondary plant metabolites. Vol. II, 2nd ed. Evolutionary and ecological processes. Academic Press, Cambridge, MA.

Sadof, C.S. and M.J. Raupp. 1996. Aesthetic thresholds and their development, p. 203-226. In: L.G. Higley and L.P. Pedigo (eds.). Economic thresholds for integrated pest management. Univ. Nebraska Press, Lincoln, NE.

Scherrer, S., C. Lepesqueur, M.C. Vieira, M. Almeida-Neto, L.A. Dyer, M.L. Forister, and I. Rezende Diniz. 2016. Seasonal variation in host plant specialization by folivorous lepidopterans: Contrasting patterns at the species and community levels. Biotropica 48:491-498.

Schwageral, C. 2016. Vanishing act: Why insects are declining and why it matters. 6 July 2016. <http://e360.yale.edu/ feature/insect_numbers_declining_why_ it_matters $/ 3012 />$.

Schwartz, J.D. 2014. Soil as carbon storehouse: New weapon in climate fight? 2 Aug. 2016. <http://e360.yale.edu/ feature/soil_as_carbon_storehouse_ new_weapon_in_climate_fight $/ 2744 />$.

Sullivan, M.L., Y. Zhang, and T.H. Bonner. 2012. Terrestrial subsidies in the diets of stream fishes of the USA: Comparisons among taxa and morphology. Mar. Freshw. Res. 63:409-414.

Tallamy, D.W. and K.J. Shropshire. 2009. Ranking lepidopteran use of native versus introduced plants. Conserv. Biol. 23:941947.

van Hengstum, T., D.A.P. Hooftman, J.G. B. Oostemeijer, and P.H. van Tienderen. 2013. Impact of plant invasions on local arthropod communities: A meta-analysis. J. Ecol. 102:4-11.

Wilson, E.O. 1987. The little things that run the world (the importance and conservation of invertebrates). Conserv. Biol. 1:344-346.

Wolf, K.L. 2014. Greening the city for health. Communities Banking 25(1): 10-12. 